\title{
PREFERENSI PENANGKAR TERHADAP PRODUKSI BENIH KELAPA SAWIT DAN KARET (STUDI KASUS PADA UPK MANDIRI SEJAHTERA - KABUPATEN SELUMA)
}

\author{
Breeder's Preference of Palm Oil and Rubber Seed Production \\ (Case study in Small Breeding Unit Mandiri Sejahtera - Seluma Regency)
}

\author{
${ }^{1}$ Sudarmansyah, ${ }^{2}$ Shannora Yuliasari, ${ }^{3}$ Wahyuni A. Wulandari, ${ }^{4}$ Andi Ishak, ${ }^{5}$ Emlan \\ Fauzi, ${ }^{6}$ Afrizon \\ 1,2,3,4,5,6 Balai Pengkajian Teknologi Pertanian Bengkulu \\ sudarmansyahvino@ymail.com
}

\begin{abstract}
ABSTRAK
Penangkaran benih tanaman perkebunan skala kecil banyak dilakukan oleh petani yang memiliki keterbatasan sumberdaya sehingga pilihan produksi benih komoditas tanaman tertentu dilakukan dengan berbagai pertimbangan. Penelitian ini bertujuan untuk mengetahui preferensi petani terhadap produksi benih kelapa sawit dan karet di UPK Mandiri Sejahtera, Desa Sarimulyo, Kecamatan Sukaraja, Kabupaten Seluma dan faktor-faktor yang mempengaruhinya. Data dikumpulkan melalui wawancara mendalam selama bulan Maret 2020 dengan satu orang informan kunci yaitu pemilik UPK Mandiri Sejahtera yang meliputi atribut penentu preferensi yaitu permintaan pasar, biaya produksi, risiko produksi, tingkat kesulitan, dan harga benih. Analisis data dilakukan secara menggunakan metode AHP. Hasil penelitian menyimpulkan bahwa bahwa petani penangkar menyukai produksi benih berturutturut adalah kelapa sawit $(83,3 \%)$ dan karet $(16,7 \%)$. Atribut yang paling menentukan preferensi petani adalah kondisi musim $(39,3 \%)$, diikuti dengan permintaan pasar $(26,3 \%)$, risiko produksi benih $(11,6 \%)$, harga jual benih $(11,5 \%)$, dan terakhir biaya produksi $(11,2 \%)$.
\end{abstract}

Kata kunci: preferensi, penangkar benih, kelapa sawit, karet. 


\section{PENDAHULUAN}

Kelapa sawit dan karet merupakan tanaman yang penting karena menjadi sumber devisi negara. Pada tahun 2018, nilai total ekspor minyak sawit dan karet remah mencapai 22.542,4 juta dollar Amerika Serikat (BPS, 2019). Pengembangan kedua komoditas tanaman perkebunan tersebut tidak lepas dari ketersediaan benihnya. Menurut Permentan Nomor 50/Permentan/KB.020/9/2015 tentang Produksi, Sertifikasi, Peredaran dan Pengawasan Benih Tanaman Perkebunan, terdapat 50 jenis tanaman perkebunan yang telah memiliki benih bina atau benih yang telah dilepas oleh Menteri Pertanian diantaranya adalah kelapa sawit dan karet.

Benih tanaman perkebunan telah dihasilkan oleh lembaga-lembaga penelitian. Pusat Penelitian Kelapa Sawit Medan misalnya menghasilkan dan menyebarkan varietas Sungai pancur 1 (Dumpy), PPKS 540, Simalungun, Avros, 540 NG, PPKS 239, PPKS 718, Yangambi, dan Langkat (PPKS, 2020). Sementara itu, Menteri Pertanian telah merekomendasikan klon unggul karet untuk produksi lateks (IRR 104, IRR112, IRR 118, IRR 220, BPM 24, PB 260, PB 330, dan PB 340), klon lateks kayu (IRR 5, IRR 39, IRR 42, IRR 230, dan RRIC 100), dan batang bawah (AVROS 2037, GT 1, PB 260, RRIC 100, PB 330, dan BPM 24) (Ditjenbun, 2018).

Perbanyakan benih unggul tanaman perkebunan dilakukan oleh produsen benih, baik lembaga pemerintah, perusahaan, atau perseorangan setelah mendapatkan Izin Usaha Produksi Benih. Produksi benih tanaman perkebunan pada tingkat perseorangan dilakukan relatif terbatas dibandingkan pada tingkat lembaga pemerintah atau perusahaan karena terbatasnya sumberdaya produsen benih. Keterbatasan sumberdaya tersebut menyebabkan produsen benih perseorangan wajib mempertimbangkan dengan seksama kriteria benih unggul bermutu secara lima tepat yaitu tepat waktu, tepat jumlah, tepat lokasi, tepat jenis, dan tepat mutu (Ditjen Bina Produksi Perkebunan, 2003) sebelum memulai proses produksi benih. Kriteria benih unggul yang dihasilkan tersebut akan sangat dipengaruhi oleh permintaan pasar untuk mengejar keuntungan sehingga seluruh pelaku usaha, termasuk produsen benih, harus mampu membaca preferensi konsumen (Kotler dan Armstrong, 2001). Waralaba benih kelapa sawit melalui kerjasama antara penangkar benih dengan perusahaan misalnya terbukti menguntungkan penangkar benih karena telah ada kepastian konsumen benih (Raisawati et al., 2013).

Preferensi secara etimologis didefinisikan sebagai kesukaan (kecenderungan hati) seseorang kepada sesuatu (Poerwadarminta, 2006). Preferensi dapat dijelaskan secara rasional jika dikaitkan dengan agribisnis. Seorang penangkar benih akan akan memilih benih apa yang akan lebih menguntungkannya apabila diproduksi dibandingkan dengan produksi benih tanaman perkebunan lainnya. Dari perspektif teori pilihan rasional, Boudon (2009) menyatakan bahwa seseorang akan memilih sesuatu hal dari berbagai pilihan yang dapat dijelaskan secara rasional yang paling menguntungkan baginya. Sumberdaya yang dimiliki individu akan menjadi penentu preferensi dari suatu tindakan rasional untuk mencapai tujuan (Coleman, 2008).

Dalam konteks preferensi produksi benih komoditas perkebunan, menarik untuk dianalisis bagaimana preferensi petani penangkar terhadap produksi benih dua komoditas utama perkebunan di Bengkulu, yaitu kelapa sawit dan karet dan faktor-faktor apa saja yang mempengaruhinya. Oleh karena itu, penelitian ini bertujuan untuk mengetahui preferensi penangkar benih terhadap 
penangkaran kelapa sawit dan karet serta faktor-faktor yang mempengaruhinya dengan mengambil kasus di UPK Mandiri Sejahtera, Desa Sarimulyo, Kecamatan Sukaraja, Kabupaten Seluma.

\section{METODE PENELITIAN}

Penelitian dilaksanakan pada bulan Maret 2020 di UPK Mandiri Sejahtera Kabupaten Seluma. Pengumpulan data dilakukan melalui wawancara mendalam untuk menggali faktor-faktor yang mempengaruhi preferensi penangkar benih terhadap penangkaran benih kelapa sawit dan karet. Informan kunci adalah pemilik UPK. Selain itu, dilakukan juga konfirmasi dengan mewawancarai 3 orang tenaga kerja yang membantu proses produksi benih.

Analisis data menggunakan metode AHP menggunakan perangkat lunak Expert Choice - 11. Model AHP disusun dengan pendekatan hirarki yang rasional dengan memasukkan seluruh pertimbangan yang dibutuhkan untuk pengambilan keputusan dan membandingkan nilai relatif antar berbagai komponen yang mempengaruhi preferensi (Handayani, 2015). Analisis preferensi dengan metode AHP terdiri atas dekomposisi hirarki dan penilaian komparatif secara logis (Walangare at al., 2012).

\section{HASIL DAN PEMBAHASAN}

\section{Profil UPK Mandiri Sejahtera}

UPK Mandiri Sejahtera telah mulai diinisiasi sejak tahun 1997, namun secara resmi didaftarkan pada tahun 2008 setelah mendapatkan pembinaan dari BP2MB Provinsi Bengkulu. Target produksi benih terutama untuk benih sebar kelapa sawit dan karet. Pada tahun 1997, produksi benih awalnya ditujukan untuk komoditas karet karena adanya dukungan ketersediaan entres yang dapat diakses di PTP 23 Napalan (sekarang PTPN 7 Pedang Pelawi, Kecamatan Sukaraja,
Kabupaten Seluma). Batang bawah dibeli dari Puslit Karet Sembawa, Sumatera Selatan. Luas lahan penangkaran UPK adalah 4 hektar. Penangkaran benih kelapa sawit baru dimulai pada tahun 2002. Denah lokasi penangkaran ditampilkan pada Gambar 1.

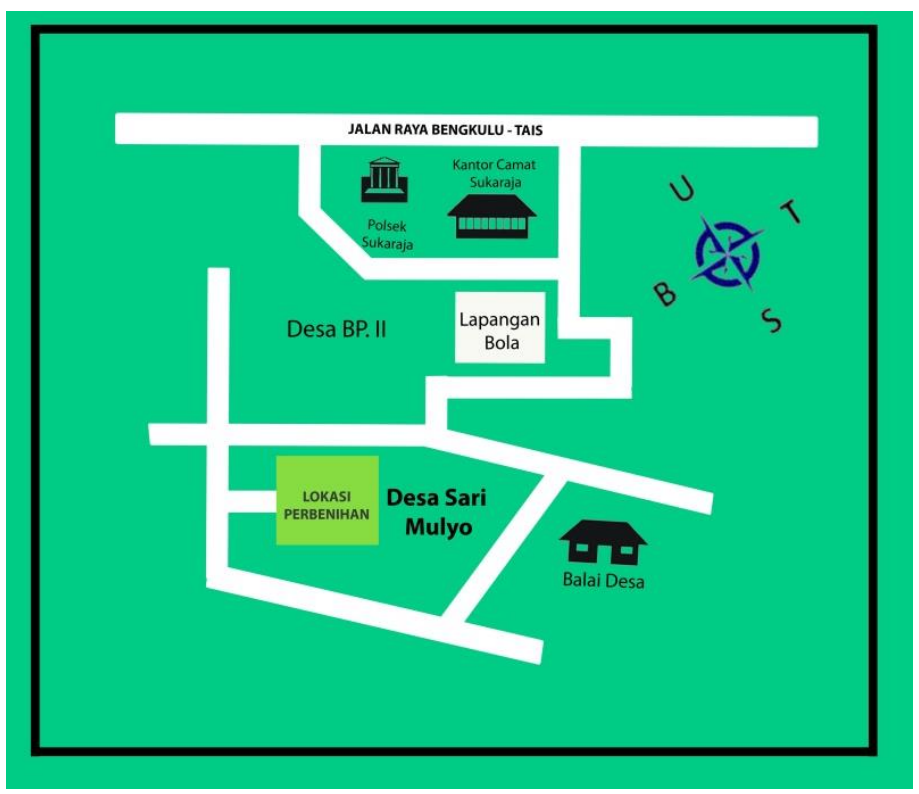

Gambar 1. Denah lokasi UPK Mandiri Sejahtera.

Hubungan yang baik dengan PTPN 7 dimungkinkan karena pemilik UPK (Bapak BS) merupakan mantan karyawan PTP sejak tahun 1980 sampai dengan tahun 1988. Bapak BS, seorang Sarjana Teknik Sipil, mengajak petani di sekitar lokasi tempat tinggalnya di Desa Sarimulyo, Kecamatan Sukaraja, untuk menanam karet karena sebagian besar masyarakat membudidayakan karet menggunakan bibit asalan yang rendah produktivitasnya.

Upaya UPK Mandiri Sejahtera merupakan salah satu anggota Asosiasi Penangkar Benih Tanaman Perkebunan (APPI) Cabang Bengkulu sejak tahun 2012. Keanggotaan dalam asosiasi menyebabkan UPK memiliki jaringan yang luas sehingga sangat membantu di dalam pemasaran benih yang diproduksinya. 
UPK memiliki kebun entres karet klon PB 260 yang mulai dikembangkan sejak tahun 2000. Pada saat ini masih terdapat 5000 batang entres pada dua lokasi kebun yang masih berproduksi. Selain kebun entres, berbagai fasilitas pendukung produksi benih juga dimiliki oleh UPK yaitu gudang, saung, sprinkle, genset, penampung air, hand sprayer, gerobak sorong, ayakan tanah, pisau entres, pisau wiwil, parang, cangkul, sekop, pelubang polibeg, dongkrak, gergaji, wadah pelilinan stump mata tidur, gunting pangkas, kendaraan operasional roda dua dan roda empat.
UPK Mandiri Sejahtera selain menangkarkan kelapa sawit dan karet juga pernah melakukan penangkaran lada, pala, kopi arabika, nangka, durian, mangga, petai, jambu mete, alpukat, sengon, dan kayu bawang. Namun selain kelapa sawit dan karet, benih tanaman lainnya diproduksi sesuai dengan permintaan dinas/instansi untuk proyek pengadaan benih tanaman perkebunan, hortikultura, maupun kehutanan. Penangkaran benih kelapa sawit dan karet dalam kurun waktu 2015-2020 disajikan pada Tabel 1. 
Tabel 1. Produksi benih kelapa sawit dan karet di UPK Mandiri Sejahtera tahun 2015-2020.

\begin{tabular}{|c|c|c|c|c|c|}
\hline \multirow[t]{2}{*}{ No. } & \multirow[t]{2}{*}{ Komoditas } & \multirow[t]{2}{*}{ Tahun } & \multirow{2}{*}{$\begin{array}{l}\text { Jumlah benih } \\
\text { (batang) }\end{array}$} & \multicolumn{2}{|c|}{ Klasifikasi usaha } \\
\hline & & & & Mandiri & Kemitraan \\
\hline \multirow[t]{6}{*}{1.} & Kelapa sawit* & 2015 & 30.000 & $\sqrt{ }$ & \\
\hline & & 2016 & 26000 & $\sqrt{ }$ & \\
\hline & & 2017 & 25.000 & $\sqrt{ }$ & \\
\hline & & 2018 & 6.000 & $\sqrt{ }$ & \\
\hline & & 2019 & - & & \\
\hline & & 2020 & - & & \\
\hline \multirow[t]{7}{*}{2.} & Karet $* *$ & 2015 & 16.000 & & \\
\hline & & 2016 & 27.000 & $\sqrt{ }$ & \\
\hline & & 2017 & 17.000 & $\sqrt{ }$ & $\sqrt{ }$ \\
\hline & & & & & $\begin{array}{l}\text { Kemitraan dengan } \\
\text { BPTP Bengkulu untuk } \\
\text { produksi } 2000 \text { batang }\end{array}$ \\
\hline & & 2018 & - & $\sqrt{ }$ & \\
\hline & & 2019 & 25.000 & $\sqrt{ }$ & \\
\hline & & 2020 & 25.000 & $\sqrt{ }$ & \\
\hline
\end{tabular}

Keterangan:

* Varietas kelapa sawit yang diproduksi adalah Simalungun yang cocok untuk lahan kering bergelombang sampai berbukit dan Dumpy untuk lahan rawa.

** Klon yang diproduksi awalnya GT-1, PR 265, dan RC100. Pada saat ini UPK menangkar klon PB 260 karena adanya kebun entres.

\section{Faktor-faktor yang mempengaruhi Penangkaran Benih Komoditas Perkebunan di UPK Mandiri Sejahtera}

Produksi benih tanaman perkebunan yang dilakukan oleh UPK Mandiri Sejahtera dipengaruhi oleh berbagai faktor yaitu faktor lingkungan (kondisi musim), proses budidaya (risiko dan biaya produksi), dan pasar (harga jual dan permintaan pasar). Ketiga faktor tersebut mempengaruhi preferensi penangkar dalam memproduksi benih kelapa sawit dan karet.

Musim penghujan merupakan saat yang cocok untuk perbenihan kelapa sawit karena mengurangi biaya penyiraman benih terutama pada fase pre nursery. Proses produksi benih sebar kelapa sawit membutuhkan waktu selama 24 bulan. Pre nursery (pengecambahan biji) berlangsung selama 3 bulan, sebelum dipindah ke polibeg ukuran $35 \times 40 \mathrm{~cm}$ atau $45 \times 50 \mathrm{~cm}$ selam 21 bulan. Pada umur 12 bulan sejak pre nursery, benih sudah dapat disertifikasi (siap salur). Masa kadaluarsa label benih setelah umur 24 bulan. Biaya yang dibutuhkan untuk produksi benih sekitar Rp. 24.000/batang dan dijual Rp. 40.000/batang. Pemasaran benih kelapa sawit relatif cukup mudah karena banyaknya permintaan baik dari petani maupun dari asosiasi.

Berbeda dengan kelapa sawit, proses produksi karet lebih cocok dilakukan pada musim kemarau. Hal ini karena tingginya curah hujan akan menyebabkan meningkatnya intensitas serangan penyakit jamur akar putih yang menjadi kendala utama dalam penangkaran karet, selain serangan kutu tempurung (Coccus viridis). Menurut Harni dan Amaria (2011), penyakit jamur akar putih menyerang seluruh fase pertumbuhan tanaman karet sejak umur Tanaman Belum Menghasilkan (TBM) yang disebabkan oleh jamur Rigidoporus microporus yang merupakan jamur saprofit penghuni tanah yang akan berubah menjadi parasit (parasit fakultatif) bila bertemu dengan akar tanaman.

Proses produksi benih karet berlangsung sampai dengan umur sekitar 1,5 tahun. Penyiapan batang bawah selama 8 bulan dan dipindah ke polibeg (stump mata tidur) sebelum proses okulasi dengan entres (batang atas). Sertifikasi dilakukan pada saat benih telah 
memiliki jumlah payung (daun tua) 1-3 payung. Biaya produksi benih sekitar Rp. 5.000/batang dan dijual dengan harga Rp. 9.500/batang. Penyiapan batang bawah, entres, dan proses okulasi menyebabkan produksi benih karet relatif lebih rumit dibandingkan dengan kelapa sawit.

Selain kendala budidaya, semakin berkurangnya permintaan benih karet juga karena menurunnya minat petani membudidayakan karet akibat rendahnya harga karet sejak tahun 2012. Lump yang dihasilkan petani karet di Desa Sarimulyo misalnya dibeli pedagang pengumpul dengan harga Rp. $7.000 / \mathrm{kg}$. Rendahnya harga karet sebagai imbas penurunan harga karet dunia yang telah terjadi sejak tahun 2012 (Gambar 2).

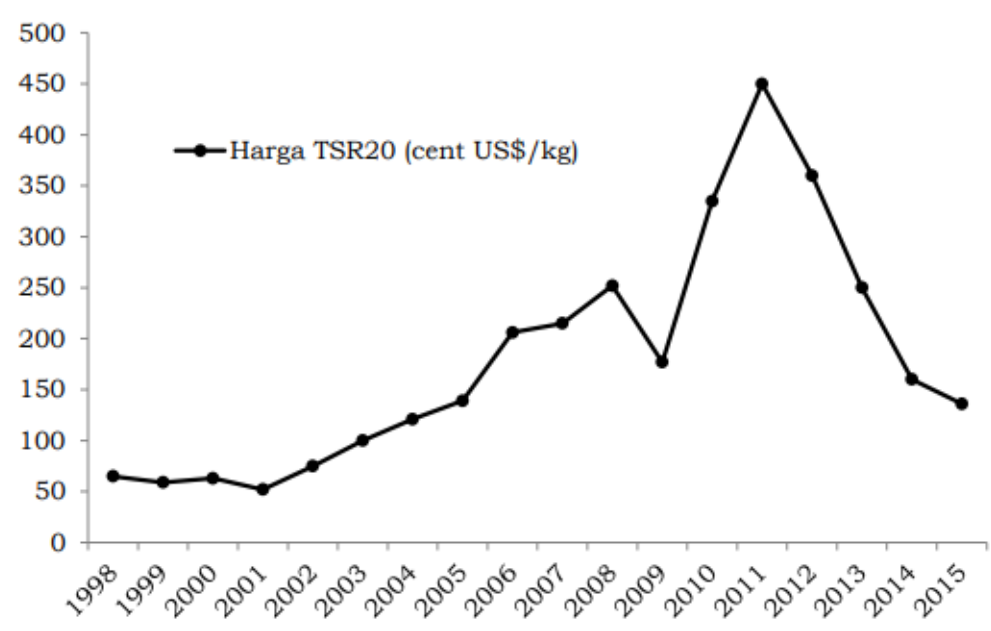

Gambar 2. Fluktuasi harga karet dunia 1998-2015 (Agustina dan Herlinawati, 2017).

\section{Preferensi UPK Mandiri Sejahtera terhadap Produksi Benih Kelapa Sawit dan Karet}

Terdapat lima atribut yang mempengaruhi preferensi petani terhadap prouduksi benih kelapa sawit dan karet di UPK Mandiri Sejahtera yaitu kondisi musim, risiko produksi (serangan hama dan penyakit), biaya produksi, harga jual benih, dan permintaan pasar. Hasil analisis preferensi menggunakan AHP menunjukkan bahwa UPK Mandiri Sejahtera lebih memilih memproduksi benih kelapa sawit dibandingkan dengan karet yang dipengaruhi oleh kondisi musim (Gambar 3).

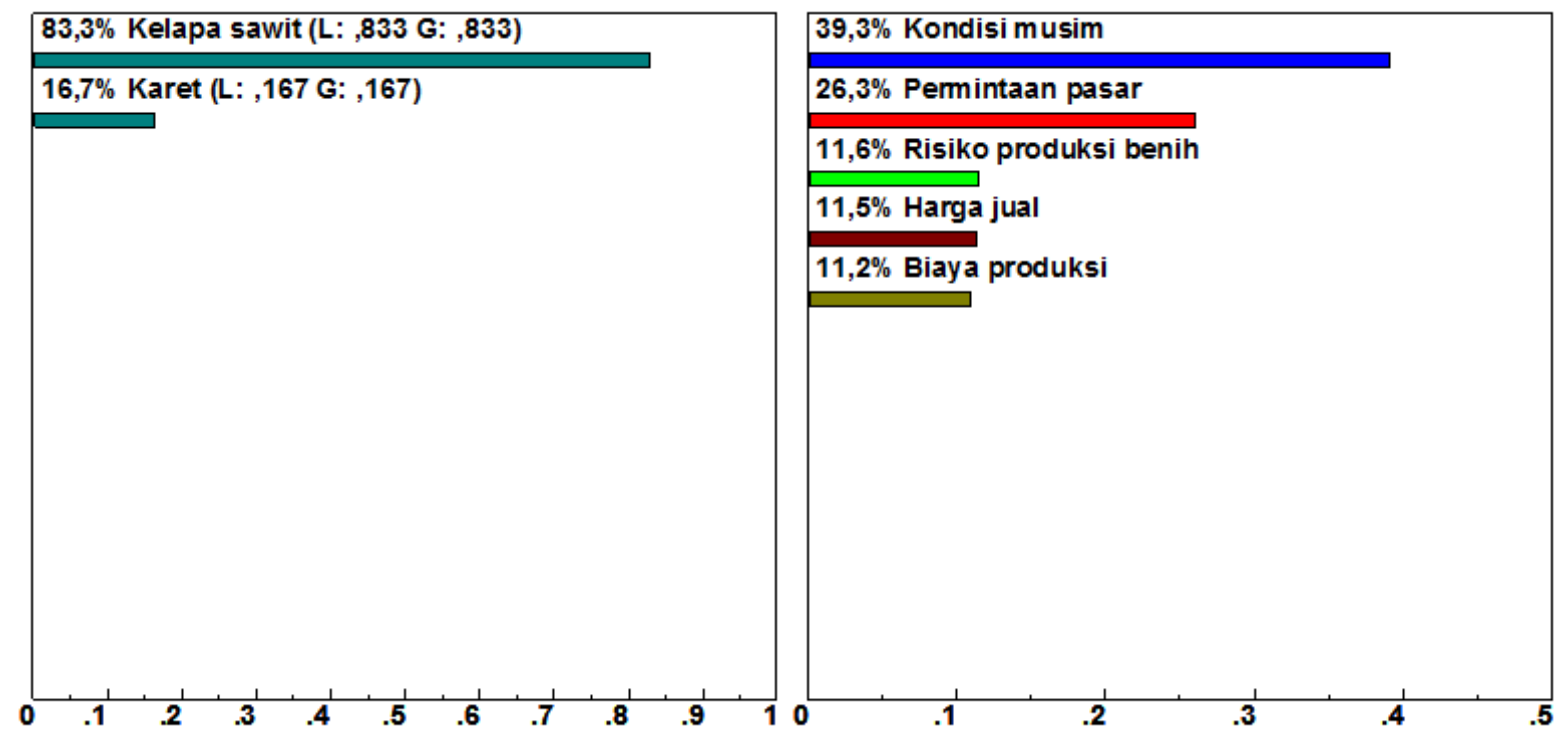


Gambar 3. Preferensi UPK Mandiri Sejahtera dalam produksi benih kelapa sawit dan karet.

Hasil analisa AHP preferensi UPK Mandiri Sejahtera pada produksi benih kelapa sawit yaitu sebesar 83,3\% sementara untuk produksi benih karet sebesar 16,7\%. Pada Gambar 3 menunjukan bahwa memproduksi benih kelapa sawit lebih menjanjikan dibandingkan dengan benih karet. Hal ini disebabkan karena permintaan pasar terhadap kebutuhan akan benih sawit cukup tinggi baik dari dalam maupun dari luar daerah, bahkan sampai antar propinsi. Sementara itu, permintaan pasar terhadap benih karet akhir-akhir ini mengalami penurunan, selain berkurangnya minat petani dalam budidaya karet dan pengaruh rendahnya harga lump karet, kurangnya permintaan pasar juga disebabkan munculnya penangkar-penangkar benih karet yang baru sehingga mengakibatkan adanya persaingan pasar. Namun produksi benih karet tetap dilakukan UPK Mandiri Sejahtera walaupun hanya dalam skala kecil, mengingat keberadaan UPK Mandiri Sejahtera yang memiliki kebun entres dan terdaftar sebagai produsen benih karet di Dinas Perkebunan Provinsi Bengkulu.

Kebijakan UPK Mandiri Sejahtera dalam menentukan sikap untuk memproduksi benih kelapa sawit sebagai pilihan utama tidak terlepas dari faktor (atribut) yang mempengaruhinya. Kondisi musim merupakan atribut yang memiliki posisi tawar yang paling tinggi yakni sebesar 39,3\% kemudian disusul oleh atribut permintaan pasar dengan nilai $26,3 \%$. Hal itu, membuktikan bahwa pengaruh musim sangat menentukan bagi UPK Mandiri Sejahtera dalam melakukan kegiatan usaha produksi benih kelapa sawit. Kondisi musim kemarau kurang cocok untuk melakukan produksi benih kelapa sawit, sesuai dengan riwayat pengalaman UPK Mandiri Sejahtera melakukan produksi benih kelapa sawit dan karet selama kurun waktu lima tahun terakhir (Tabel. 1), yakni pada tahun 2019 yang lalu UPK Mandiri Sejahtera tidak melakukan kegiatan produksi benih kelapa sawit dikarenakan di tahun 2019 kondisi kemarau yang cukup panjang.

Sementara permintaan pasar bagi UPK Mandiri Sejahtera pengaruhnya berada di posisi kedua, terutama untuk permintaan benih kelapa sawit tidak memiliki kendala, namun lain halnya dengan permintaan pasar benih karet lebih mengandalkan pesanan petani dan memenuhi paket (proyek) pengadaan Lembaga/Dinas Pemerintah. Atribut risiko produksi benih menduduki posisi ketiga yaitu sebesar 11,6\%, selanjutnya harga jual benih sebesar $11,5 \%$, dan yang terakhir biaya produksi dengan bobot nilai sebesar 11,2\%.

Ketiga atribut ini bagi UPK Mandiri Sejahtera pengaruhnya dalam usaha produksi benih kelapa sawit maupun benih karet tidak begitu dominan, untuk atribut risiko produksi benih, kecil kemungkinan terjadi dikarenakan pemilik UPK Mandiri Sejahtera memiliki pengalaman yang cukup panjang di berbagai perusahaan yang bergerak di bidang perkebunan dan hampir selama pengabdiannya di perusahaan yang memperkerjakannya selalu ditempatkan pada bagian pembibitan dan produksi benih. Sedangkan atribut harga jual benih, keikutsertaan UPK Mandiri Sejahtera dalam anggota Asosiasi Penangkar Benih Tanaman Perkebunan (APPI) memungkinkan bagi mereka untuk selalu menjaga stabilitas harga jual benih. Biaya produksi, yakni atribut yang pengaruhnya memiliki bobot paling rendah, banyaknya aset yang dimiliki dan tingginya kepercayaan pihak Bank di daerah Kabupaten Seluma terhadap UPK Mandiri Sejahtera, hal ini membuktikan bahwa untuk biaya produksi benih kelapa sawit dan karet cukup mudah mendapatkannya. 


\section{KESIMPULAN DAN SARAN}

Penelitian ini menyimpulkan bahwa UPK Mandiri Sejahtera lebih menyukai produksi benih kelapa sawit dari pada karet. Atribut yang paling menentukan preferensi penangkar benih adalah kondisi musim, diikuti dengan permintaan pasar, risiko produksi benih, harga jual benih, dan biaya produksi. Berdasarkan hasil penelitian ini, disarankan agar dalam produksi benih bukan saja aspek ekonomi yang menjadi pertimbangan namun juga aspek lingkungan budidaya perlu mendapat perhatian untuk kesuksesan usaha penangkaran benih kelapa sawit dan karet. 


\section{DAFTAR PUSTAKA}

Agustina, D.S. dan E. Herlinawati. 2017. Komparasi Kelayakan Investasi Klon Karet GT 1 dan PB 260 pada berbagai Tingkat Harga dan Umur Ekonomis. Jurnal Penelitian Karet 35(1):83-92.

Boudon, R. 2009. Rational Choice Theory. The New Blackwell Companion to Social Theory (ed. B. S. Turner). Hlm 179-195.

BPS. 2019. Analisis Komoditas Ekspor 2012-2018 Sektor Pertanian, Industri, dan Pertambangan. Badan Pusat Statistik. Jakarta.

Coleman, J.S. 2008. Dasar-dasar Teori Sosial. Nusa Media. Bandung.

Direktorat Jenderal Bina Produksi Perkebunan. 2003. Waralaba Benih Tanaman Perkebunan. Warta Pusat Penelitian Kopi dan Kakao Indonesia, 19(3):131-145.

Ditjenbun. 2018. Kementan tingkatkan Kompetensi Manajemen Tanaman Karet. Direktorat Jenderal Perkebunan. Jakarta. Sumber: http://ditjenbun.pertanian.go.id/kementantingkatkan-kompetensi-manajemen-tanaman-karet/https://www.iopri.org/bahantanaman-ppks/, diunduh tanggal 15 April 2020.

Handayani, R.I. 2015. Pemanfaatan Aplikasi Expert Choice Sebagai Alat Bantu dalam Pengambilan Keputusan (Studi Kasus: PT. Bit Teknologi Nusantara). Jurnal Pilar Nusa Mandiri 11(1):53-59.

Harni, R. dan W. Amaria. 2011. Penyakit Jamur Akar Putih dan Cokelat pada Jambu Mete dan Strategi Pengendaliannya. Buletin RISTRI 2(2):215.

Kotler, P. dan G. Armstrong. 2001. Prinsip-prinsip Pemasaran Jilid 1. Penerjemah Damos Sihombing. Penerbit Erlangga Jakarta.

Poerwadaminta,W.J.S. 2006. Kamus Besar Bahasa Indonesia Edisi III. Balai Pustaka. Jakarta.

Puslitkoka. 2019. Pedoman Tarif Pelayanan Jasa dan Harga Produk Tahiun 2020. Pusat Penelitian Kopi dan Kakao Indonesia. Jember.

PPKS. 2020. Karakteristik Varietas Kelapa Sawit Produksi PPKS. Pusat Penelitian Kelapa Sawit. Medan. Sumber: https://www.iopri.org/bahan-tanaman-ppks/, diunduh tanggal 15 April 2020.

Raisawati, T., E. Susilo, S. Handayani. 2013. Kajian Waralaba Bibit Kelapa Sawit di Bengkulu. Jurnal Agroqua, 11(1):46-51.

Walangare, D., R. Delima, dan Restyandito. 2012. Sistem Prediksi Pertandingan Sepak Bola dengan Metode Analytical Hierarchy Process (AHP). Informatika 8(2):181-188. 